\title{
A Case Study of an Internationalization Process of a Private Higher Education Institution in Malaysia
}

\author{
Abdul Rahim Abu Bakar" and Asmat Nizam Abdul Talib ${ }^{b}$

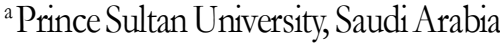 \\ ${ }^{\mathrm{b}}$ Universiti Utara Malaysia
}

\begin{abstract}
The increasing competition and commercialization of higher education has led to the internationalization of Higher Education Institutions (HEIs) around the world. While internationalization appears to be inevitable, differences are apparent in its definitions, depth, scope and mode. The main aim of this paper is to assess the internationalization efforts of Malaysian HEIs through a case study on the internationalization process of one private HEI. The case highlights various weaknesses of the internationalization effort in the institution. The symptoms and the causes of the problems in the institution corroborate similar findings in other studies involving the internationalization of HEIs. Suggestions and recommendations are presented to enable other organizations that wish to undertake similar internationalization efforts to learn from the case study institution's experience.
\end{abstract}

Abstrak: Meningkatnya persaingan dan komersialisasi pendidikan tinggi telah menyebabkan Internasionalisasi Perguruan Tinggi (HEIs) di seluruh dunia. Sementara internasionalisasi tampaknya tak terelakkan, perbedaan yang jelas dalam definisi, kedalaman, ruang lingkup dan modus. Tujuan utama dari makalah ini adalah untuk menilai upaya internasionalisasi HEIs Malaysia melalui studi kasus pada proses internasionalisasi satu HEI pribadi. Kasus ini menyoroti berbagai kelemahan dari upaya internasionalisasi lembaga. Gejala-gejala dan penyebab dari masalah dalam lembaga menguatkan temuan serupa di studi lain yang melibatkan internasionalisasi HEIs. Saran dan rekomendasi disajikan untuk memungkinkan organisasi lain yang ingin melakukan upaya yang sama internasionalisasi untuk belajar dari pengalaman studi kasus lembaga itu.

Keywords: case study; higher education institution; internationalization; Malaysia

* Corresponding authors. E-mail: drrahimbakar@gmail.com, or aabubakar@fnm.psu.edu.sa 


\section{Introduction}

The advent of globalization, advanced information technology and increased transnational travel has enabled higher education institutions (HEIs) in many countries to expand their services beyond their traditional territorial boundaries. Knight (2004) argues that internationalization is changing the world of higher education (HE) and that globalization is changing the world of internationalization. In this era of business globalization, HEIs are being challenged to follow suit (Stromquist 2007). Many authors seem to suggest that internationalization is a solution (Hua et al. 2011).

As a result, more and more HEIs are becoming internationalized and market-oriented. Accordingly, the literature on globalization of $\mathrm{HE}$ has begun to proliferate in the last few years (Sharma and Roy 1996). A growing number of HEIs are emphasizing the importance of internationalization in their institutional policies and strategies, and internationalization has become one of the driving forces behind HE policies in many countries (Ayoubi and Massoud 2007; Van Vught et al. 2002; Wende 2002). These initiatives appear not only among private institutions but also within public HEIs and in developing economies - namely the Asia-Pacific region. Mestenhauser (2005) has pointed out that there is broad agreement among scholars and practitioners that internationalization is no longer a choice but has become an urgent necessity. Evidence of this urgency can be found in the 2005 International Association of Universities (IAU) survey, which revealed that the vast majority of institutional leaders around the world believe that internationalization is of utmost importance, and that the number of HEIs that have moved from an ad hoc to a planned approach to internationalization has increased.

While there appears to be a general consensus that HEIs have no alternative but to go for internationalization (Sharma and Roy 1996), differences are apparent in the definition, depth, scope, and mode of internationalization (Beamish and Calof 1989; Dunning 1989). In addition, there is little empirical evidence to illuminate the nature and extent of integration of internationalization into the strategic missions of individual institutions (Ayoubi and Massoud 2007). We also do not know much about the challenges faced by institutions in their quest to implement internationalization. An understanding of these issues is necessary for the effective development and management of internationalization in HEIs (Nga 2009).

Although there is an increased use of and attention attached to internationalization (Knight 2004), there is a great deal of confusion about what it really means. The term remains ambiguous and unclear (Knight 1997; Stier 2003; Yang 2002) while the language of internationalization is changing and differs within and between countries (Knight 2005). A review of the literature shows that there are many definitions, terms, approaches and interpretations of HEIs internationalization. Internationalization seems to have several different definitions and approaches, and these varying interpretations have led to confusion and doubt as to the validity of its benefits to higher education (Absalom and Vadura 2006).

This is a central issue in HE, especially for those leading and managing the internationalization of a university. They need to agree on what internationalization means in order to consider the strategies required to accomplish it. This confusion is also likely to 
have hindered attempts by individual institutions to internationalize. The same difficulty also flows down into how to agree on and develop an effective strategic focus ( $\mathrm{Nga}$ 2009).

Consequently, the primary purpose of this paper is to assess the internationalization motivations and efforts based on a case study of one private HEI in Malaysia. This is done first through a brief review of the literature on the internationalization of HEIs and then a focus on the Malaysian initiative - particularly the institution under review. The paper then discusses the internationalization efforts of this Islamic based private HEI through a reflective case study highlighting the challenges and problems --particularly the low admission rate of foreign students in this institution.

\section{Definition of Internationalization of $\mathrm{HEI}$}

Over the last decade, it has been noted that the definition of the term "internationalization" has evolved. Internationalization was first commonly defined at the institutional level and in terms of a set of international activities. Later, many definitions evolved as researchers and authors debated the term from different angles, e.g. strategic management (Horn et al. 2007; Stromquist 2007), organizational learning, and leading strategic change (Soderqvist 2002). The term has been borrowed by different people for different purposes (Hua et al. 2011).

One widely cited definition comes from Knight (2005) who defines HEI internationalization as the process of integrating an international, intercultural or global dimension into the purpose, functions or delivery of post-secondary education. Compared to other authors, Knight's definition extends beyond the curriculum to the whole university and proposes "integrating an international dimension into the teaching, research and service functions of an institution of higher education." Elkin and Devjee (2003) suggest that internationalization should "aim to create values, beliefs and intellectual insights in which both domestic and international students and faculty participate and benefit equally. They should develop global perspectives, international and cultural and ethical sensitivity along with useful knowledge, skills and attitudes for the globalised market place."

Although or perhaps because the definition of internationalization has evolved into more wide-ranging dimensions, the practical implementations within HEIs remain in disarray. As we argued earlier, as the definition varies between authors and nations, we believe so do the rationales behind the internationalization of HEIs. The different perspectives of internationalization in HEIs, as mentioned by different scholars, present unique emphases and approaches for different stakeholders. It seems that internationalization of HEIs is a complex process and presents profound implications for the various stakeholders involved (Sirat 2009).

\section{Dimensions of Internationalization in $\mathrm{HEI}$}

Generally, there are two main dimensions of HEI internationalization: internationalization at home and cross-border education. "Internationalization at home" is purely domestic and refers to the international and intercultural dimension of curriculum that is to teaching and research that helps students develop international and intercultural skills without ever leaving their home country (Knight 2003, 2005; and Nilsson 1999). Cross-border education on the other hand 
refers to a situation where in the student, teacher, researcher, program, institution, provider and/or course materials cross national jurisdictional borders (OECD 2004).

Huisman and van der Wende (2004) on the other hand distinguish between the more traditional forms of internationalization and anew form. The traditional form of internationalization has been as an add-on activity, embodied in marginal and short-term policies based on temporary funding mechanisms as projects, and focusing mainly on the international mobility of students and academic staff. In general, internationalization was rarely integrated into regular planning and evaluation, and hardly ever into any form of regulation (Kalvermark and van der Wende 1997; van der Wende 2001; Virkus and Tammaro 2005).

However, in the new form of internationalization, two main $\mathrm{HE}$ trends or approaches can be identified: 1) an ongoing imperative of HEIs to internationalize - to integrate an international/intercultural dimension into teaching, research and community service - in order to enhance their academic excellence and the relevance of their contribution to societies; and 2) the growth of market-driven activities, fuelled by increased demand for $\mathrm{HE}$ worldwide, declining public funding in many nations, the diversification of HE providers, and new methods of delivery such as the internet (IAU 2006).

\section{The Competing Rationales of Internationalizing HEIs}

The rationale that motivates a move towards internationalization varies by country and by institution. Historically, internationalization in higher education has been motivated by the wish to promote mutual understanding; the need for the migration of skilled workers in a knowledge-based economy; the desire to generate revenue for the higher education sector; or the need to build a more educated workforce (generally found in emerging economies). Aigner et al. (1992) suggested three reasons why HEIs embrace internationalization: 1) interest in international security; 2) maintenance of economic competitiveness and 3) fostering of human understanding across nations. These factors, Aigner et al. (1992) argue, have led to four different policy approaches to internationalization of HEIs which are:

- mutual understanding approach

- skilled migration approach

- revenue-generating approach

- capacity building approach

The mutual understanding approach encompasses political, cultural, academic and development aid goals. It allows and encourages mobility of domestic as well as foreign students and staff through scholarship and academic exchange programmes and supports academic partnerships between educational institutions. This approach does not generally involve any strong push to recruit international students. Examples of countries using this approach so far are Japan, Mexico, Korea, or Spain. The European Union's Socrates-Erasmus programme also corresponds to this approach, involving student and teacher exchanges, networking of faculties and institutions across Europe and joint development of study programmes (OECD 2004a).

The skilled migration approach shares the goals of the mutual understanding approach but gives stronger emphasis to the recruitment of selected international students and aims to attract talented students to work 
in the host country's knowledge economy, or make its higher education and research sectors more competitive. Scholarship programs may remain a major policy instrument in this approach but they are supplemented by active promotion of a country's higher education sector abroad, combined with an easing of the relevant visa or immigration regulations. Sometimes, specific services are designed to help international students in their studies and their stay abroad and more teaching takes place in English. This approach can have a variety of targets, such as students from certain areas, postgraduates or research students rather than undergraduates, or students in a specific field. This approach generally results in a rise in the number of international students. Examples of countries having adopted this approach are Germany, Canada, France, the United Kingdom (for EU students) and the United States (for postgraduate students).

The revenue-generating approach shares the rationales of the mutual understanding and skilled migration approaches, but offers higher education services on a more or less full-fee basis, without public subsidies. Compared to domestic students, foreign students generate additional income for institutions which are encouraged to become entrepreneurial in the international education market. Under this strategy, governments tend to grant institutions considerable autonomy and seek to secure the reputation of their higher education sector and protect international students, for example through quality assurance arrangements. This may be complemented by an active policy to lower the barriers to cross-border education activities through trade negotiations in educational services under the General Agreement on Trade in Services (GATS) or other agreements. This approach generally results in a significant growth of fee-paying student mobility and in strong involvement in cross-border education through revenue-generating program and institution mobility. Examples of this approach are Australia, the United Kingdom (for non-EU students), New Zealand, and the United States (OECD 2004a).

Finally, the capacity-building approach encourages cross-border higher education, however delivered, as a relatively quick way to build an emerging country's capacity. Scholarship programs supporting the outward mobility of domestic civil servants, teachers, academics and students are important policy instruments; so is encouraging foreign institutions, programs and academic staff to come and operate for-profit ventures, generally under a government regulation which ensures their compatibility with the country's nation and economy building agendas. Twinning arrangements and partnerships with local providers are encouraged (and sometimes compulsory) in order to facilitate knowledge transfers between foreign and local institutions. In the short run, this approach results in large numbers of out-going students and of foreign revenue-generating educational programs and institutions. Examples of this approach are mostly found in Southeast and North Asia and in the Middle East, e.g. Malaysia; Hong Kong, China and Singapore.

Knight (1999) on the other hand provides a different framework for understanding the different rationales in HEI internationalization. These are:

- political rationales, often driven by national government lies in the national interest of invoking international understanding in order to secure international political stability and world peace; 
- economic rationales, primarily the desire to use HE to help a nation or region compete in the global market by being internationally competitive through a well-educated, well-trained workforce that possesses up-to-date knowledge and experiences that are relevant for the challenge of a globally connected, dynamic and demanding market;

- academic rationales, including the desire to meet international standards of quality in teaching, research and service; and

- cultural and social rationales, primarily the focus on the development of individual learners to improve the quality of their lives in addition to the preservation of national culture as well as the advancement of intercultural awareness.

\section{The Internationalization Efforts of HEIs}

The internationalization initiatives proposed by Aigner et al. (1992) and Knight (1999) seem to resemble the effort done by HEIs worldwide. For instance, HEI sees internationalization as a revenue-generating or economic rationale. There is a growing trend to see education as an export product. With demand for HE increasing at an exponential rate, both large and small countries are viewing the export of educational products and services and the import of foreign students as a major part of their HE policy. Hence, there is a shift in view, from seeing education as merely a development assistance activity or cultural program towards seeing it as an export commodity. Thus, there is an increasing number of HEIs shifting to adopt a market-oriented approach which highlights the economic rationale for the internationalization of higher education.
Making money seems to be a significant motive for HEI internationalization projects in the for-profit sector as well as for some traditional non-profit universities experiencing financial problems (Altbach and Knight 2007). This corroborates a few studies that view financial incentives as the main stimulus for internationalization (Gornitzka and Maassen 2000; Poole 2001). Davies (1992) for instance argued that internationalization in HEIs is "closely linked with financial reduction and the rise of academic entrepreneurialism." Many countries recruit international students to boost profits by charging them high fees; these include Australia, Canada, the United Kingdom, and the United States. This could be due to the tight fiscal situation facing HEIs today, and places international activity in the context of revenueproducing work. International graduate students also provide research and teaching services for modest compensation, and international students spend significant amounts of money in their host countries. Concurrently, developing countries are hosting a significant number of international students; they seek to attract foreign students to their universities to improve the quality and cultural composition of the student body, gain prestige, and earn income. China, Malaysia, and India are actively developing strategies to attract students and to export educational programs and institutions. India for instance hosts more than 8,000 students from abroad each year, of which 95 percent are from developing countries (Bhalla 2005).

Consequently, many HEIs are also focusing on the academic rationales which are the desire to meet international standards of quality in teaching, research and service. IDP Education Australia for instance, using projections based upon 25 selected countries, 
estimates that the number of international students looking for learning opportunities either in or from a foreign country will reach 1.4 million in 2010 and rise to 3.1 million in 2050 (Line Verbik 2007). With an expected global population of seven to eight billion by 2025 , it is estimated that there would be some 125 million students by 2020 . With the active developments in this sector, it is anticipated that Asia will dominate the global demand for international $\mathrm{HE}$ for the next two decades. Bohm et al. (2002) forecast that the global demand for HE will increase from 1.8 million international students in 2000 to 7.2 million international students in 2025 . If current trends continue, by 2025 Asia will represent some 70 percent of the total global demand. In addition, countries like Hong Kong, Singapore and Malaysia aim to create world class universities capable of attracting the very best students. Hence, their national governments have been allocating more funds to higher education to improve the quantity and quality of tertiary education being offered (Mok 2008).

Therefore, it is apparent that policies on internationalization of HE have been on the rise in developing Asian countries such as India, China, Indonesia and Malaysia. Driven by motives of academic and economic rationales, HEIs in the Asia-Pacific regions are seriously promoting their higher education services overseas. The pressure for these institutions to internationalize their programs derives from two sources. From the supply side, they need to make their programs more relevant to potential international customers and to increase their customer base, since the markets for some programs have reached maturity or begun to decline. From this angle, internationalization is a good strategy for increasing market profile, international image, diversification, and opportunities for new in- come (Mazzarol 1998; Saffu and Mamman 2000; Trim 2001).

On the demand side, there are pressures for developing economies to "modernize" and "internationalize" their industrial development by diversifying their workforce's education background. The increasing pace of HEI internationalization is also a response to a wide range of conditions, including competitiveness of the global economy and the desire for colleges and universities to produce globally competent graduates (de Wit 2002). Finally, institutions' heightened awareness of other countries and cultures has caused an explosion of efforts to internationalize HE. International linkages give overseas students an opportunity to gain professional knowledge and to experience other cultures and educational systems (Horie 2002; and Poole 2004).

\section{Internationalization Efforts of Malaysian HEIs}

Malaysia is currently ranked eleventh in the World Education Service Report in relation to preferred destinations for higher education. The country has turned out to be an emerging provider in global $\mathrm{HE}$, attracting more than 70,000 international students in 2009 (Sawahel 2009). In Malaysia, the education sector is a major contributor to the nation's economy, with each international student estimated to spend at least RM30,000 (approximately US $\$ 10,000$ ) per year in the country throughout the course of his study, which translates to more than RM2 billion for the 70,000 international students residing in the country. The sector has grown tremendously over the year that it has become a big business. Merill Lynch estimated that the education business worldwide generates roughly US $\$ 2$ trillion per year (Radin Sohadi 
2009). Malaysian private HEIs alone contribute RM1.3 billion annually to the national economy; a large percentage of this comes from revenue obtained from international students.

Coherently, the Malaysian National Higher Education Strategic Plan (PSPTN) gave emphasis to a comprehensive internationalization effort capable of making Malaysia as a regional hub with a 200,000 international student's enrolment by 2020 . This vision has been sustained over the years by its reiteration in the Seventh, Eighth and Ninth Malaysia Plans ( $7^{\text {th }}$ MP: 1996-2000; $8^{\text {th }}$ MP: 2001-2005; $9^{\text {th }}$ MP: 2006-2010). In 2004, a separate Ministry of Higher Education was established to raise standards in higher education by producing graduates that meet the human capital needs of the country, and making Malaysia a regional and international hub of educational excellence.

The Malaysian government (NEAC 2009) views internationalization effort as a process that will:

1. Attract and retain the best talent for the country's growth

2. Elevate Malaysia's current standing from a manufacturing-focused, middle-income country to a high-income, knowledge- and talent-driven country and

3. Contribute towards nation-building by promoting intercultural understanding and cultural diversity in society, hence increasing Malaysians' international awareness and developing a sense of national pride.

These views resemble the academic and cultural social rationales based upon Knight (1999) conceptualization. Consequently, as the blueprint of the internationalization efforts of HEIs are "directed" by the government, this internationalization effort has a political rationale. As Cheung (2002) argued, the higher education in developing countries, particularly in South East Asia presents significant features. As reiterated earlier, one of the features is the gearing of higher education towards meeting economic needs. This has been manifested by policies to reduce educational imports, increased educational exports, change curricula and enrollment (Tan 2006). Meanwhile, the second dominant features is the interventionist role of governments in controlling and directing major policy decisions concerning higher education institutions towards prescribed social and economic goals (Nga 2009). Hence, in the case of Malaysia, democratization of higher education was state driven and it was adopted as the principal avenue. Coherently, top-down policy was the order of the day where each HEIs in Malaysia has taken their own initiatives in internationalization.

At the same time, Malaysian public and private HEIs (MoHE 2007) view internationalization as a process that will:

1. Accelerate the implementation of critical national agenda items

2. Form a potentially lucrative source of revenue generation and

3. Strengthen institutions' capacity.

The HE system in Malaysia consists of 20 government-funded universities, 37 private universities and university colleges and more than 500 private colleges. It is recorded that 18,242 international students enrolled in 2001 (Badaruddin 2010) and in ten years, it has grown to 86,919 international students, with about 16 percent growth per annum. According to Sirat (2008), the flow of international students into Malaysia has increased steadily since 1996, when various reforms were introduced to streamline the entry of 
international students into HEIs. Currently, international students represent less than 5 per cent of all tertiary enrolments in Malaysia. However, under the Malaysian Higher Education Strategic Plan, the country aspires to become a hub of excellence for HE internationally by 2020 , with 200,000 international students $(10 \%$ of enrolment) in its HEIs.

The internationalization effort was further boosted when several international universities were given the go-ahead to operate their branch campuses on Malaysian soil. Currently, there are eight foreign HEIs operating in the country, namely; Monash University, Curtin University of Technology, Swinburne University of Technology, from Australia, Nottingham University, HeriotWatt University, the Medical Faculty of the University of Newcastle and The University of Reading from the United Kingdom and the Manipal University of India.

Ranking and survival of universities have put much pressure on both public and private universities in Malaysia to attract international students in the recent decade. There is tremendous growth in the number of international students studying in the public and private HEIs in Malaysia. Nevertheless, as the private HEIs set up are more commercially driven, hence these institutions target for undergraduate international students, because there is more demand for this programs. Private HEIs are motivated to attract international students as it is the main source of income for the corporations through tuition fees. Based on the trend, about 70 percent of international students enrolled at Private HEIs. With that, this institution will therefore house approximately 105,000 international students or 70 percent of 150,000 by 2015 .
On the other hand, a majority of international students in Malaysian public HEIs pursue postgraduate degrees (Masters and Ph.D.). Currently, of the 532 Private HEIs operating in Malaysia, only 200 are allowed to recruit international students (Yean and Yi 2008). The purpose of this restriction is to safeguard the reputation of Malaysian HEIs by allowing only certified and "quality assured" institutions to be open to international students.

\section{A Case Study of the Internationalization Effort of a Malaysian HEI}

In this section we describe a case study of the internationalization effort of one private HEI in Malaysia. The name of the institution includes the term "International," indicating that the institutionis actively involved in international student marketing and recruitment. The institution has 8 colleges and 41 academic programs. These include an MBA program offered by the Graduate Studies Centre, 12 bachelor's programs, 25 diplomas, and 5 Foundation programs. Islamic studies disciplines are taught in Arabic while English is the medium of instruction for the rest of the academic programs. Although the institution has started to offer conventional business, social science and science-related courses, it has tended to retain its focus as a "theology" HEI. Apart from this institution, almost all of the 14 states in Malaysia have similar private colleges. In addition, the country has other established HEIs that are that have a similar academic programs located in the capital city. Almost all of these institutions (private and public) offer the same products and services and are competing for the same market segment. 
In 2008 , the respective institution had a total of 5,475 students of which 170 were international students representing 14 countries. Based on these statistics, international students represented a meagre 3.2 percent of the student population, which falls short of the institution's target of 10 to 20 per cent, according to the institution's Vice President of Student Academic Affairs. The institution believes that international student recruitment is important in maintaining their image as an "international institution" and enriching the educational and cultural process while meeting the financial targets set by the stakeholders. The institution started recruiting international students in 1999, but the current enrolment of international students is far below the target set by the stakeholders. The international student enrolment trend has been fairly consistent every year since 1999, with the international student intake less than 5 percent.

\section{Methods}

Based on the poor results of international student recruitment, this present study was undertaken to investigate the possible causes and to provide recommendations on how to improve it. A combination of focus groups, face-to-face interviews and document analysis was used to obtain data to identify issues regarding the institution's internationalization. In the face-to-face interview, a senior member of the administrative staff with direct responsibility for internationalization at the institution was interviewed. Meanwhile, two sessions of focus group interviews were conducted. The first group consisted of four members of the administrative and teaching staff while the second group consists of five students of various nationalities, courses of study and seniority (number of semesters). Participation in the former group was by invitation based upon their role in the "internationalization" process. The selection was done based on their job specifications and duties assigned. A letter was then send to the respective individual with an accompanying letter from the institution's registrar requesting them to cooperate. Meanwhile, with the help of the program head of department, two lecturers were identified that match the profile of the focus group. Both parties (administrators and academicians) were later contacted to relay the information of the intended event.

Meanwhile the latter group was comprised of volunteers. An invitation to participate in the student focus group was posted on the institution's information board. To encourage the student's participation, participants were given a gift as an incentive and a letter from the dean of student's affairs department acknowledging their contribution.

The duration for the former focus group lasted about two hours while the latter group ends within 90 minutes. A request was made to record the conversation in the focus group. However, all the participants denied the request although they were assured that their details would be treated with strict confidentiality or that their identity would be kept anonymous. Therefore, to comprehend the situation, the focus groups comprise of two moderators with the lead moderator asking and leading the questions while the second moderator ensures that all the questions pertinent to the subject of study were asked. In addition, the second moderator acts as a note taker whiles the lead moderator observes the participants body language and probes pertinent information in an unstructured manner. The data gathered during the interviews and focus group discussions were analyzed through data grouping. 
Relevant institutional documentation about internationalization in the institution was gathered to provide a basis for corroborating and triangulating evidence from other data-gathering strategies (Hammersley and Atkinson 1983; Silverman 1993). Information that identifies internationalization as an institutional priority is accessible on the institution's website. Internationalization is explicitly included in the institution's vision, which is "to become a world class Islamic higher education institution" (website). The institution's website also mentioned that it strives to become an institution of higher learning of an international status. In addition, the institution's newsletter Horizon Bulletin includes news coverage of international memorandum of understanding (MOU) events comprising international academic collaboration and research.

\section{Findings}

It was apparent that the institution is competing in an almost commodity-like market, with similar other HEIs established in the fourteen states of the country in addition to the public HEIs that offer similar programs and target similar market segments. Subsequently, an analysis was conducted by the academic affairs department during one of the institution's retreats. Headed by the deputy Vice President of Academic Affairs, the exercise included administrative staffs in charge of academic programs and also faculty members that hold specific positions in the institution. The analysis revealed that one area of weakness was that the institution did not have good brand recognition. A "rebranding" in 2004 which changed the institution's name has confused people's perceptions about the institution. A second area of weakness was that the institution has only a small percentage of Ph.D. holders among the academic staff, which limits its programs to only diplomas and bachelor's degrees. Finally, the analysis also revealed that the budget for international marketing activities was relatively small, to the extent that the impact was basically not visible.

Looking at the international student composition, the institution's focus is on recruiting from neighboring countries such as Singapore, Thailand, and Brunei although there are a minority of students from African nations such as Somalia and Nigeria. As students from neighboring countries share a common lingua franca (Malay), it is easier for students from these countries to mingle and communicate with the local students. The interview findings related to international students narrows down to one common element: language. The institution's information, administrative staff and campus environment are dominated by the Malay language and this stifles international students' academic and cultural development. As one diploma student from Singapore, pointed out:

Obviously there is no general information in Arabic language. On the other hand, the environment in our campus is using less English though it is a medium in teaching and learning...even the staff members are not using English. If we look at the information board, there is no other language except it is in Malay language. It may be troublesome for international students who do not know the Malay language.

These problems corroborate the results of previous studies on the internationalization of HEIs, which identified issues of cultural identity, cultural shock and language barriers (Bakalis and Joiner 2004; Pritchard and Skinner 2002; Thorstensson 2001; Yen and Stevens 2004). Meanwhile, the interviews 
with the institution staff in the focus group saw them blaming university management for the current situation. For instance, the administrative staff in charge of internationalization affairs revealed their frustration:

One of the issues is related to the unclear policy and lack of support from the top management with regards to the internationalization future and its direction. Where do we go from here? Yes, we have increasing number of international students enrolled into our programs yearly but internationalization involves more than just recruiting foreign students. The main objective of [the] internationalization office as its office bearer for international activities in a way will help the university to promote international culture and awareness among the staff. However, that function is currently limited to technical aspect of visa and student pass processes only.

The findings of the administrative focus group revealed that they felt there was no specific strategic planning regarding the internationalization process. The institution was concerned simply with increasing the number of foreign students from all parts of the world in order to make the student body "international" in line with the institution's name. The analysis of the focus group and the academic affairs staff during the retreat revealed the following findings:

- No specific allocation of funds for international marketing activities.

- A limited number of marketing staff to execute tasks in international marketing activities to cater to a wider market segment (ASEAN and regional countries, African countries, China and Middle Eastern countries).

- Minimal or no training given to staff members to enable them to perform effective marketing and promotion activities or deal with intercultural issues of the students.

- A lack of coordination among faculties and departments regarding the "internationalization" process in terms of medium of instruction, course syllabus or course program.

- No central task force within the institution responsible for handling international student marketing and promotional issues.

Due to the unclear direction and commitment from university administration, faculty members believe that "internationalizing the lectures" through the use of English or Arabic would only jeopardize the performance of the local students. Hence, quite a number of the lecturers continue teaching in the local Malay language or mix the language of their lectures between Malay and English/ Arabic. This creates confusion and dissatisfaction among the foreign students as they are unable to follow the lectures and discussions in class. In addition, as English or Arabic language proficiency among the domestic students was relatively low, they tend to dissociate themselves from the Arabic and English speaking students.

Data gathered from the interviews were subjected to data grouping by which similar issues (themes) and their relationships were identified. Problem identification was done through the "fish bone" technique which further illustrated the above-mentioned problems (see Figure 1). Obviously, the absence of a centralized committee to look at and monitor the internationalization process - in this instance, student marketing and recruitment- is the core problem contributing to the overall poor performance of the institution's internationalization efforts. This problem leads to the subproblems of limited budget allocation for international student market- 
ing and recruitment, lack of dedicated staff and poor inter-functional control. These are considered as first-tier problems. Following this, the study identified a lack of specification of job duties or tasks, incompetent busi- ness acumen of staff and poor marketing plan(s) as second tier problems. Figure 2 illustrates the interrelationship of these problems resulting in overall poor international student recruitment.

\section{Figure 1. Problem Identification Illustrated through Fish Bone Analysis}

\section{$1^{\text {st }}$ Tier Problem}

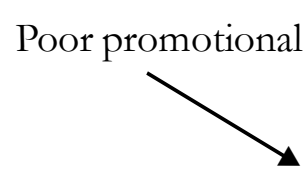

Poor awareness among

potential students

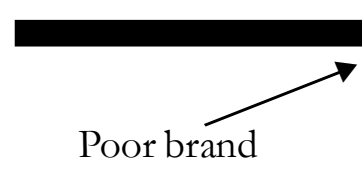

recognition

Limited promotional activities

\section{$2^{\text {nd }}$ Tier Problem}
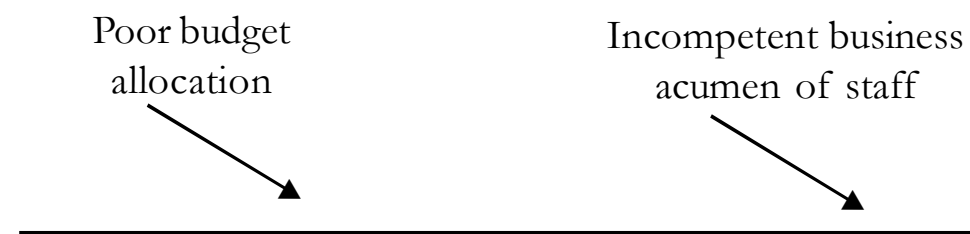

Poor Marketing Planning

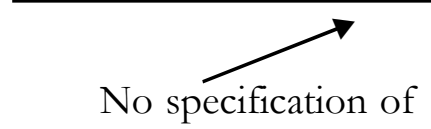
job duties/tasks (countries

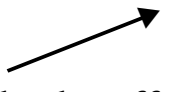

No International Marketing Department

Skeletal staffs

\section{$3^{\text {rd }}$ Tier Problem}

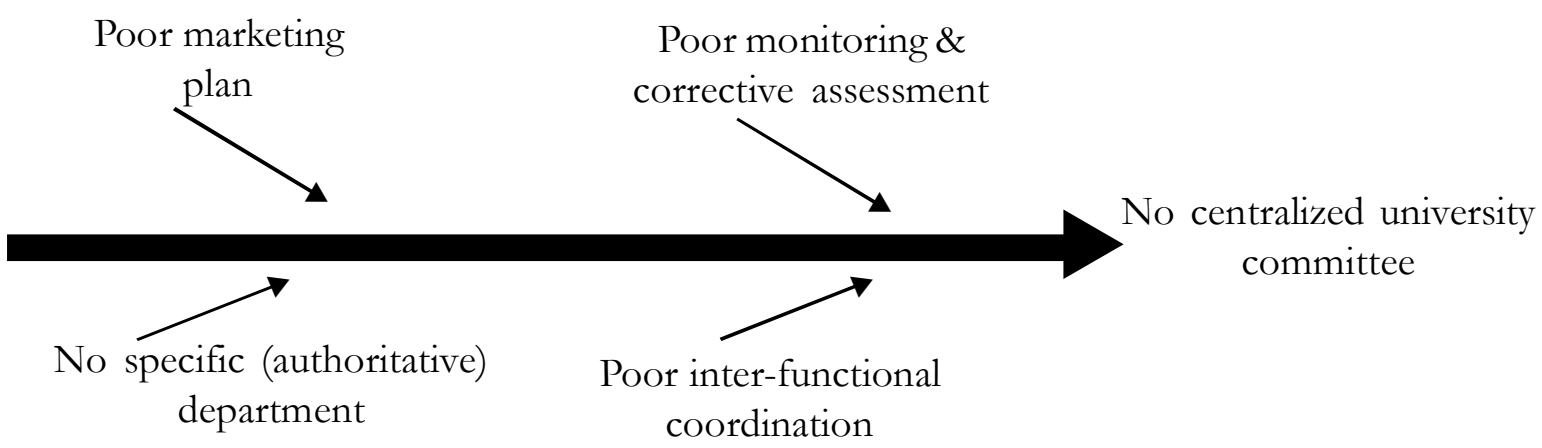


Figure 2. SIUC Internationalization Problems

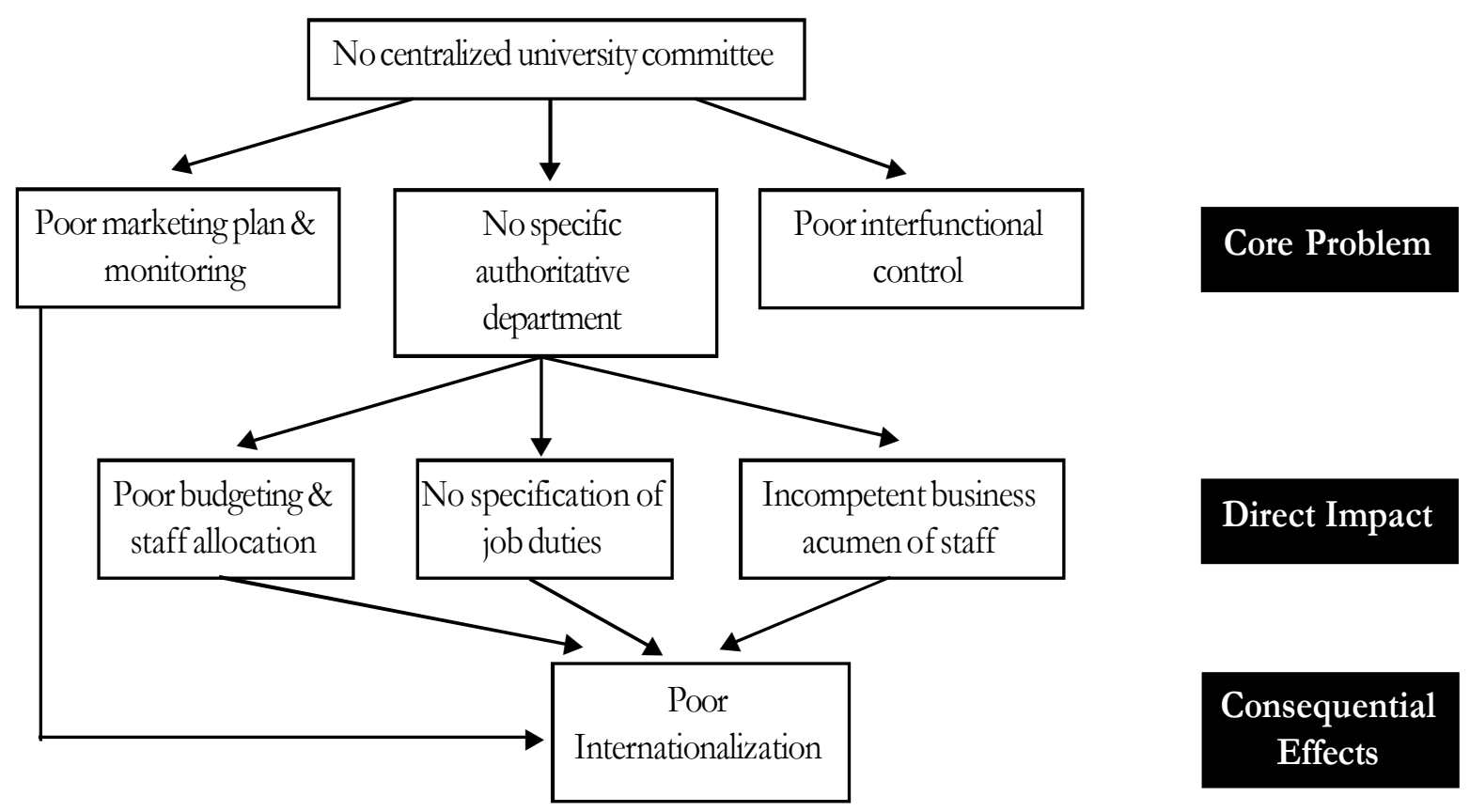

\section{Discussion and \\ Recommendation}

The findings of the case study corroborate the findings of studies on other HEIs that faced similar problems in their internationalization process. Initially, as illustrated in the case study findings, most of the international activities operate independently without campus-wide coordination. As Stier (2002) argues, "universities struggle to overcome organizational obstacles, traditions and collective attitudes that prevent administrators and teaching staff from cooperating sufficiently and adequately." The findings in this case study present insights into faculty reflection and conceptualization processes that took place without the guidance of scholarly and administrative expertise in the field of HEIs. Faculty perspectives emphasized decentralized faculty leadership and a culture of academic freedom. Hence, the lecturers took it upon themselves to either teach in "[an] international language [i.e., English/ Arabic]" or Malay depending on their perspective.

The findings from this study are also in line with what have been practising in other Malaysian HEIs, to the extent that a university which is specifically dedicated to promote national language at a tertiary level is also offering courses and degree programs in English in order to cater to the needs of foreign students (Abd. Aziz 1994). This phenomenon of promoting the use of English as a medium of instructions is not limited to just a few HEIs but applies to all HEIs all over the country (Rethinasamy and Chuah 2011). As Knight (2004) states, “...it is usually at the institutional level that the real process of internationalization is taking place" (pp. 6-7). As Altbach and Knight (2007) state, "globalization may be unalterable, but internationalization involves many choices" (p. 291). 
It was also clear that the necessary strategic oversight and development of international initiatives had been neither conducted nor communicated by the management of the institution. Knight (2005) argued that "without a clear set of rationales, followed by a set of objectives or policy statements, a plan or a set of strategies and a monitoring or an evaluation system, the process of internationalization is often an ad hoc, reactive and fragmented response of the overwhelming number of new internationalization opportunities available." As such, there was a lack of communication, coordination and connection among activities across the campus. This corroborates the findings of an earlier study undertaken by the British Columbia Centre for International Education in 1993, in which it was found that most international activities operate independently and discretely rather than in a campus-wide infusion effort. Knight (1994) argues that the fragmentation and marginalization of international activities prevents HEIs' efforts from reinforcing each other and from having any leverage in the institution.

As such, the internationalization process remains a daunting challenge (Francis 1993) wherein the absence of coordination leads to other barriers such as a lack of tangible and attitudinal commitment. It is evident from the data that internationalization had not been considered systematically or in a coordinated way or in other words - done in an ad hoc basis. There are no established written policies regarding internationalization and the matter has not been taken into consideration in the university's strategic planning. This supports earlier findings by Audass (1990) who argued that the absence of tangible and attitudinal commitment from senior administrators leads to little or no recognition for international work in hiring or pro- motion, and no central focus point in the university to introduce, support and service internationalization activities. Other obstacles to internationalization that have been highlighted in previous studies that appear similar to this study include financial problems (Gahungu 2001; Harper 1995), cultural difficulties (Canto and Hannah 2001; Brook 2000; Dunn and Wallace 2004; Olson and Kroeger 2001), development problems (Audenhove 1998) and individual commitments (Brown 1998).

In the case study institution, administrative approaches to internationalization are not yet clear on an operational level, and we have been unable to identify any specific policies and procedures implemented for purposes of internationalization review and planning. More significantly, although internationalization is articulated as an institutional priority, it seems to be a low priority for institutional infrastructure support, funding, and communications efforts. To expand the internationalization process in HEIs, Harari (1989) advocated that the institution must improve its commitment and consensus building. He argued that support from senior administrators in both tangible and non-tangible form is a prerequisite, although the non-tangible is the most critical. He believes that it may be unrealistic to expect all staff to be committed to internationalization, but that a critical mass of 10-15 percent is necessary to operationalize a commitment. The support across campus will be more effective when it is initiated through and nurtured by a consensus-building approach. This effort depends on strong leadership from the top in the form of clear direction in policy and mission statements, appropriate structures for coordination of activities, and incentives and rewards for faculty and students (Harari and Reiff 1993). 
Finally, it is obvious that the institution tries to stretch its budget when it comes to international promotion and marketing, since it is a costly endeavour. Göthenberg (2012) argues that successful internationalization activities depend on several factors including the profile, strength and capabilities of the HEIS. These capabilities include language proficiency, administrative routines to manage international students, staffs and much more. Therefore, Bevist and Murry (2003) argued that universities need to look for creative ways to get more results from their educational budget. Our study illustrates that it is important to comprehensively define internationalization activities in today's competitive higher education environment, because diminishing institutional resources often challenge internationalization efforts.

\section{Conclusion and Recommendation}

Not surprisingly, the experience of the case study institution in internationalizing its student recruitment exhibited the same problems faced by other HEIs in other economies. The crux of the problem seems to lie in the absence of strategic direction which leads to lack of commitment and consensus from the top management. By rectifying this problem the institution would be able to iron out the structural and non-tangible issues so that the whole campus can and will commit to the idea of internationalization. It is important that a "critical mass" of internationalization subscribers and believers exists within the HEI. A firm strategic direction of internationalization from the institution's management would provide a strong drive to the staffs (academic and administrative), clear policies and financial allocation. Locally based private institutions like Lim Kok Wing University, INTI University, SEGI University and the like are examples of local institutions which have a clear focus of internationalization and have grown to become successful HEIs in terms of foreign intake as well as going off-shore. Lim Kok Wing university for instance, since its humble appearance in 1991, has opened international campus branches in London (United Kingdom), Botswana, Lesotho, Swaziland, Indonesia, Cambodia and China.

In conclusion, while admitting that it is impossible to generalize from our single case study, we nonetheless propose a few general recommendations to higher education administrators based on our findings. First, intention or passion for internationalization itself is not sufficient for an organization to proceed. Internationalization requires resources, support, and strategic coordination - and therefore must be an institutional strategic priority. Second, internationalization must be addressed systematically. There must be mutual understanding of institutional goals, rationales, and objectives for comprehensive internationalization. Third, internationalization must take the form of an individual/institutional partnership. The faculty cannot take the responsibility of implementing full institution-wide internationalization, and the institution's administrators cannot implement a comprehensive internationalization process, without coordination with, support of, and participation by the faculty. Finally, while findings from this case study may not be generalizable, valuable lessons have nonetheless been learned that may be transferred to internationalization processes underway at other institutions of higher learning. 


\section{References}

Abd Aziz, M. S. 1994. Attitudes towards English: A Survey of UKM Undergraduates. Akademika 44 (1): 85-99.

Absalom, M., and K. Vadura. 2006. Student perceptions of internationalization of the curriculum. Arts and Humanities in Higher Education 5: 317-334.

Aigner, J. 1992. Internationalizing the University: Making It Work. Springfield, Virginia: CBIS Federal, Inc.

Aigner, J. S., P. Nelson, J. Stimpfl. 1992. Internationalizing the university: Making it work. Springfield, VA: CBIS Federal.

Altbach, P. G., and J. Knight. 2007. The internationalization of higher education: motivations and realities. Journal of Studies in International Education 11 (3/4): 290-305.

Audas, M. C. 1990. Comparing policy statements and practices in the international dimension of selected institutions of higher education. International Education Forum 10 (2): 59-73.

Ayoubi, R. M., and H. M. Massoud. 2007. The strategy of internationalization in universities, a quantitative evaluation of the intent and implementation in UK universities. International Journal of Education Management 21: 329-349.

Beamish, P. W., and J. L. Calof. 1989. International business education: A corporate view. Journal of International Business Studies 20 (3): 553-64.

Bhalla, V. 2005. International students in Indian universities. International Higher Education 41: 8-9.

Bohm, A., T. Davis, D. Meares, and D. Pearce. 2002. Global Student Mobility 2025: Forecasts of the Global Demand for International Higher Education. Australia: IDP Education.

Cheung, A. B. L. 2002. Public service reform in Singapore: Reinventing Singapore in a global age. In Cheung A. B. L., and I. Scott (eds.), Governance and Public Sector Reform in Asia: Paradigm Shifts or Business as Usual? (pp. 138-162). London: Routledge Curson.

Davies, J. 1992. Developing a strategy for internationalization in universities: Towards a conceptual framework. In C. B. Klasek, B. J. Garavalia, and K. J. Kellerman (Eds.), Bridges on the Future: Strategies for Internationalizing Higher Education (pp. 177-190). Carbondale-Illinois: Association of International Education Administration.

de Wit, H. 1995. Strategies for the Internationalization of Higher Education: A Comparative Study of Australia, Canada, Europe and the United States of America. Amsterdam, Holland: European Association for International Education.

de Wit, H. 2002. Internationalization of Higher Education in the United States of America and Europe: A Historical, Comparative, and Conceptual Analysis. Westport, Connecticut: Greenwood Press.

Dunning, J. H. 1989. The study of international business: A plea for a more inter-disciplinary approach. Journal of International Business 20 (3): 411-36.

Elkin, G. R., J. Farnsworth, and A. Templer. 2008. Strategy and internationalization of universities. International Journal of Educational Management 22 (3): 239-250.

Elkin, G. R. and F. Devjee. 2003. Visualising the 'Internationalisation' of Business Schools: In The Challenge of International Business (Proceedings of the ANZIBA International Business Academy Conference). Dunedin: Australia New Zealand International Business Academy. CD ROM 8 pages.

Francis, A. 1993. Facing the Future: The Internationalization of Post-Secondary Institutions in BritishColumbia. Vancouver: British Columbia Centre for International Education. 
Gornitzka, A., and P. Maassen. 2000. The economy, higher education, and European integration: An introduction. Higher Education Policy 13 (3): 217-23.

Göthenberg, A. 2012. Strategic Internationalization in Sweden: 1-40. Stockholm, Sweden: The Swedish Foundation for International Cooperation in Research and Higher Education.

Hammersley, M., and P. Atkinson. 1983.Ethnography: Principles in Practice. Tavistock, London.

Harari, M. 1989. Internationalization of Higher Education: Effecting Institutional Change in the Curriculum and Campus. Long Beach, California: Center for International Education, California State University.

Harari, M., and R. Richard. 1993. Halfway there: A view from the bridge. International Educator 3 (1): 1619.

Li-Hua, R., J. Wilson, G. Aouad, and X. Li. 2011. Strategic aspects of innovation and internationalization in higher education, the Salford PMI2 experience. Journal of Chinese Entrepreneurship 3 (1): 8-23.

Huisman, J., and M. C. van der Wende. 2004. On cooperation and competition. National and European policies for internationalization of higher education. ACA Papers on International Cooperation, Lemmens, Bonn.

Horie, M. 2002. The internationalization of higher education in Japan in the 1990s: A reconsideration. Higher Education 43: 65-84.

Horn, A. S., D. D. Hendel, and G. W. Fry. 2007. Ranking the international dimension of top research universities in the United States. Journal of Studies in International Education 11 (3/4): 330-58. Sage.

Verbik, L., V. Lasanowski. 2007. International Student Mobility: Patterns and Trends. London: The Observatory on Borderless Higher Education.

Kalvermark, T., and M. C. van der Wende. 1997. National Policies for the Internationalization of Higher education in Europe. Stockholm: National Agency for Higher Education.

Knight, J. 1994.Internationalization of Canadian universities. Unpublished PhD Dissertation. Michigan State University.

Knight, J. 1999.Internationalization of Higher Education. Paris: OECD.

Knight, J. 2003. Internationalization of Higher Education Practices and Priorities: 2003 LAU Survey Report. Retrieved from http://www.unesco.org/iau/internationalisation.html

Knight, J. 2004. Internationalization remodelled: definition, approaches, and rationales. Journal of Studies in International Education 8 (1): 5-31.

Knight, J. 2005.Crossborder education: Programs and providers on the move. Research Monograph. Ottawa: Canadian Bureau for International Education.

Knight, J. 2005. An international model: responding to new realities and challenges. In De Wit, H., I. C. Jaramillo, J. Gacel-Ávila, and J. Knights (Eds). Higher Education in Latin America: The International Dimension (pp. 31-68). Washington, USA: World Bank Publications.

Knight, J. 2006. Cross border education: an analytical framework for program and provider mobility. In J. C. Smart (Ed.), Higher Education: Handbook of Theory and Practice (pp. 207-227). Dordrecht. The Netherlands: Springer Academic Publishers.

Knight, J. and de Wit, H. 1997.Internationalization of higher education in Asia pacific countries, EAIE, Amsterdam. 
Mazzarol, T. 1998. Critical success factors for international education marketing. International Journal of Educational Management, 12 (4): 163-75.

Mestenhauser, J. (2005). Internationalization at home: Rethinking campus internationali-zation. In. E. M. Hayle (Eds.), Educational Benefits of Internationalizing Higher Education: The Students' Perspective. Retrieved from http://qspace.library.queensu.ca/bitstream/1974/1006/1/ Hayle_Elaine_ M_200801_MEd.pdf

Ministry of Higher Education Malaysia. 2006. Strategic Plan for International Marketing of Higher Education in Malaysia 2006-2010. Kuala Lumpur, Malaysia.

MoHE. 2007. National Higher Education Strategic Plan 2007-2020. Malaysia: Ministry of Higher Education Malaysia.

Mok, K. H. 2008. Varieties of regulatory regimes in Asia: the liberization of the higher education market and changing governance in Hong Kong, Singapore and Malaysia. The Pacific Review 21 (2): 147-170.

NEAC. 2009. New Economic Model for Malaysia (Part 1).Putrajaya: NEAC.

Nga, J. 2009. The internationalisation of Malaysian private higher education institutions for increasing higher education exports. DBA Thesis. Lismore, NSW: Southern Cross University.

Nilsson, B. 1999. Internationalization at home: Theory and praxis. EAIE Forum (Spring). Amsterdam: EAIE.

Ninnes, P. and M. Hellsten. 2005. Introduction: critical engagement with the internationalization of higher education. In P. Ninnes, and M. Hellsten (Eds.), Internationalizing Higher Education: Critical Explorations of Pedagogy and Policy (pp. 1-8). Netherlands: Springer.

OECD. 2004. Internationalization and Trade of Higher Education: Challenges and Opportunities, Organization for Economic Co-operation and Development. Paris.

OECD. 2004a Internationalization of higher education. Organization for Economic Co-operation and Development. Paris.

Poole, M. 2004. Diversity of the student body and social cohesion. Paper presented at the12th General Conference: The Wealth of Diversity, IAU Sao Paulo Conference, July 25-29.

Poole, D. 2001. Moving towards professionalism: the strategic management of international education activities at Australian universities and their faculties of business. Higher Education 42: 395-435.

Radin Sohadi, R. U.. 2009. Malaysia as an international education hub: Policy implications. Keynote Address and Paper presented at the Seminar on Managing International Students: Issues and Challenges, Awana Genting Highlands Golf and Country Resort, Pahang.

Rethinasamy, S., and K. M. Chuah. 2011. The Malaysian University English Test (MUET) and its use for placement purposes: A predictive validity study. Electronic Journal of Foreign Language Teaching 8 (2): $234-245$.

Saffu, K., and A. Mamman. 2000. Contradictions in international tertiary strategic alliances: thecase from down under. The International Journal of Public Sector Management 13 (6): 508-18.

Sawahel, W. 2009. MALAYSIA: Knowledge hub in progress. University World News (94) (27 September). Retrieved from http://www.universityworldnews.com/article.php?story=20090925024920661

Scott, R. A. 1992. Campus Development in Response to the Challenges of Internationalization: The case of Ramapo College of New Jersey. Springfield, Virginia: CBIS. 
Silverman, D. 1993. Interpreting Qualitative Data: Methods for Analysing Talk, Text and Interaction. London: Sage.

Sharma, B. and J. A. Roy. 1996. Aspects of the internationalization of management education. Journal of Management Development 15 (1): 5-13.

Sirat, M. 2009. Contemporary Issues in the Global Higher Education Marketplace. Pulau Pinang: IPPTN.

Sirat, M., and A. R. Ahmad. 2008. Policy for a changing world. Prospect Malaysia (June): 20-23.

Stier, J. 2003. Internationalization, ethnic diversity and the acquisition of intercultural competencies. Intercultural Education 14 (1): 77-91.

Stromquist, N. P. 2007. Internationalization as a response to globalization: radical shifts in university environments. Higher Education 53 (1): 81-105.

Tan, J. 2006. Higher education in Singapore. In Higher Education in South East Asia. APEID, UNESCO.

Yean, T. S., and A. K. J. Yi. 2008. Trade and Investment Linkages in Higher Education Services in Malaysia (pp: 161-87). Retrieved October 14, 2008, from http://www.unescap.org/tid/publication/tipub 2469_chapter 6.pdf

Trim, P. R. J. 2001. An analysis of a partnership arrangement between an institution of further education and an institution of higher education. Journal of Further and Higher Education 25 (1): 107-16.

van der Wende, M. C. 2001. Internationalization policies: about new trends and contrasting paradigms. Higher Education Policy 14: 249-59.

van Wende, M. C. 2002. New Perspectives for Learning: Briefing Paper 60: Higher Education Institutions' Responses to Europeanization, Internationalization and Globalization. Available at: www.pjb.co.uk/npl/bp60.pdf

van Vught, F., M. Van der Wende, and D. Westerheijden. 2002. Globalisation and internationalization: policy agendas compared. In Enders, J. and Fulton, O. (Eds), Higher Education in a Globalising World. International Trends and Mutual Observations (pp. 103-21). Dordrecht: Kluwer Academic Publishers.

Virkus, S. and A. Tammaro. 2005. Models of academic cooperation in European LIS education. Proceedings of the EADTU Annual Conference 2005 towards Lisbon 2010:Collaboration for Innovative Content in Lifelong Open and Flexible Learning, Rome, 10-11November 2005, available at: www.eadtu.nl.

Welch, A. 1996. Australian Education: Reform or Crisis. Sydney: Allen \& Unwin.

Yang, R. 2002. University internationalization: its meanings, rationales and implications. Intercultural Education 13 (1): 81-96. 
